\title{
Effect of some biofertilizers ( pgpr, biosoal and compost tea)on growth, yield, fiber quality and yarn properties of egyptian cotton.(promising hybrid 10229xg86).
}

\author{
Zewail, R. M. Y.and Ahmed, H. S.A." \\ Agric. Botany Department, Faculty of Agric., Benha Univ. Egypt. \\ "Cotton Research Institute, Agricultural Research Center, Giza, Egypt.
}

\begin{abstract}
Experiments of this study were conducted at the Faculty of Agriculture, Moshtohor, Benha University Fiber and yarrn properties were conducted at cotton research institute, Agric. Res. Center, Giza Egypt during 2013 and 2014 seasons The effect of applying biofertilizers with the recommended rates as soil addition With the plant growth promoting Rizobactria(PGPR)and Biosoal as well as foliar spray with PGPR ,biosoal and compost tea.were studied Also, the combinations of PGPR+ biosoal; PGPR+ compost tea and PGPR + biosoal+ compost tea. Different applied treatments were added through plant growth at,45,65,85and 105 days after sowingduring 2013 and 2014 seasons. At 125 days after sowing i.e., 20 days after the last addition and /or spray vegetative growth,yield, chemical analysis, some yield components and fiber\& yarn properties were estimated.The most important results can be summarized as follows:

Different applied treatments increased growth characteristics i.e., plant height, number and total area of leaves/ plant, number of vegetative and fruiting branches/plant and total chlorophyll during bothgrowing seasons. The most effective treatments upon growth characteristics were the combination of PGPR+ Biosoal+Compost Tea. Also, yield and yield components i.e. bolls weight/plant, seed cotton yield (g)/plant and (kantar)/ feedan, lint weight $(\mathrm{g}) / \mathrm{plant}$, lint $\%$ and seed yield index as well.In addition,the treatment of mixed bacteria strains when applied in form of foliar spray PGPR+Biosoal +compost tea increased mineral nutrients i.e.N, P, K,Ca, Mg, Fe, Zn and Cu contents in Egyptian cotton leaf at 125 days after sowing during 2013 \&2014 seasons. Furthermore, fiber physical and mechanical properties of yarn under different applied treatments were increased.
\end{abstract}

Keywords: Egyptian cotton promising 10229G 86,PGPR ,Biosoal, compost tea,seed cotton yield, fiber properties.

\section{Introduction}

Egyptian cotton (Gossypium barbadense L.) is the most important commercial fiber crop in Egypt. Cotton still plays a key role in the economic activity. It is the oldest among the commercial crops and is termed as white gold. Plant growth enhancement was used to improve lint yield, fiber quality and yarn properties. Previously, the common means to achieve these aims were through the use of desirable genetics in the form of well-adapted high-yielding varieties. Also, plant growth substances either endogenously were stimulated to form by cotton plants through many treatments or even exogenously were applied (Maheshwari et al., 2012).That are applied directly to a target plant to alter its physiological processes or its structure to improve quality, increase yields, or facilitate harvesting control, prevent undesirable late vegetative growth of plants, and enhancing fruiting could be achieved. They like promoters, inhibitors in which play a key role in control mechanism of plant growth.

Nowadays, some bacterial genera as well as many other biofertilizers are being applied to many plants to alter their physiologically and anatomically behaviors to get vigorous growth and enhance fruiting as well vital components of soils. They are involved in various biotic activities of the soil ecosystem to make it dynamic for nutrient turnover and sustainable for crop production (Chandler et al.,2008 and Ahemad and Khan,2011 and 2012). They stimulate plant growth through mobilizing nutrients in soils, producing numerous plant growth regulators, protecting plants from phytopathogens by controlling or inhibiting them, improving soil structure and bio remediating the polluted soils by sequestering toxic heavy metal species and degrading xenobiotic compounds (like pesticides) (Braudet al., 2009 Hayat et al.,2010; Rajkumar et al., 2010; Ahemad and Malik, 2009and Ahemad, 2010). Indeed, the bacteria lodging around/in the plant roots (rhizobacteria) are more versatile in transforming, mobilizing the nutrients compared to those from bulk soils (Hayat et al., 2010). Therefore, the rhizobacteria are the dominant deriving forces in recycling the soil nutrients and consequently, they are crucial for soil fertility (Glick, 2012). Currently, the biological approaches for improving crop production are gaining strong status among agronomists, botanists and environmentalists following integrated plant nutrient management system.

Plant growth promoting Rizobactria (PGPR) in Egyptian agriculture has become more apparent since the completion of the high Dam, which resulted in the deposition of the suspended Nile silt upstream from the formed lake. This Nile silt was a source of 
K-bearing mineral that enriched the soils during the growth of seasonal foods.Deficiencies can limit the accumulation of crop biomass. This has been attributed to a reduction in the partitioning of assimilates (Glick, 2012)In this respect.Biofertilizers are of the most important organic fertilizers in this respect,Ambergerig (1993) defined the biofertilizers as inoculation with several soil bacteria and fungi notably the species of Pseudomonas, Bacillus, Penicillium and Aspergillus those are being secrete organic acids and lower the $\mathrm{pH}$ which facilitate the solubility of minerals in the soil. Also, he added that Pseudomonas spp. are receiving worldwide attention under the broad general category known as plant growth promoting rhizobacteria (PGPR) or plant health promoting rhizobacteria. In addition, Patten, and Glick, and Etesami et al.,(2009) explained that PGPR strains, able to augment the plants by interfering the concentration of known phytohormones that those bacteria one of the most important way affect the growth and development is by producing Indole-3 acitic acid (IAA) that led to improve root growth and development and subsequently increase uptake of nutrients. increased the yield potential and fiber properties of the Egyptian cotton .Similar results were obtained by Dhale et al.,(2011) who found that the use of bioinoculents are beneficial in improving yield parameters (weight of bolls, number of bolls per plant, seed cotton yield) and fiber quality parameters (span length, uniformity ratio, micronaire value, tenacity, EIG\%,)up to some extent.

Biosoal is mixed of multi strains of biofertilizer Bactria to increase plant growth and productivity by increase mineral uptake, growth promoting creation in rhizosphere and in extract thereby, increase plant integrity, as well.

Furthermore, Compost tea water based extracts of compost (compost tea) has a relatively long history in agriculture. This is not surprising since they are simple to make by soaking compost in water and agitating by stirring, aeration or other methods. Scientific investigations of claims of the benefits of compost tea are much more recent. Study results have been variable, but there is considerable evidence that compost extracts can improve plant production by decreasing disease incidence, improving plant nutrient status and generally promoting plant growth (Arancon et al., 2007; Hargreaves et al., 2008; Ingham, 2005). These water extractable components include: active microorganisms, primarily bacteria, fungi and some protozoa,mineral nutrients, organic acids and other microbial bio products. So,considerable variability in the efficacy of compost tea to promote plant growth has been reportedby Al-Kahal et al., (2009).

Generally, this study aimed to determine the effect of PGPR, biosoal and compost tea as soil addition or foliar sprayed on vegetative and reproductive growths and balanced between them to attain efficient cotton productivity, maximize yield traits and to get high quality of fiber properties of Egyptian cotton promising hybrid $10229 *$ G86

\section{Material and methods}

These experiments were conducted at the Agriculture Experimental farm at Faculty of Agriculture, Moshtohor, Benha University Egypt and fiber and yarn properties were conducted atCotton Research InstituteAgriculture Research Center Giza Egypt during 2013 and 2014 seasons to study the effect of soil addition and foliar spray with some bacterial strains as biofertilizer PGPR and biosoal as soil addition and foliar spray with and compost tea; PGPR and biosoal as well as some of their combinations on growth, yield, chemical composition, some yield components and fiber \& yarn properties of Egyptian cotton promising hybrid $10229 *$ G86 .

Biofertilizers treatments were conducted in Randomize complete block design (RCBD in 5 rows) in plot $3 \times 3.5 \mathrm{~m}^{2}$ during) in three replicates two seasons.

\section{Experiments were included two methods of application: \\ A-Soil addition:}

At sowing time seeds were inoculated with each of Plant Growth Promoting Rizobactria (PGPR) and biosoal that were repeated through plant growth four times at 45,65,85 and 105 days after sowing with the irrigation water.

B-Foliar spray: At the assigned time of foliar spray that started at45 days /after sowing; plants were sprayed until the run of spraying solutions and repeated with interval of 20 days) (the last spray was at 105 days after sowing) with each of the following extracts:

1- Plant Growth Promoting Rizobactria (PGPR) .2- Biosoal. 3- Compost Tea. 4 PGPR + biosoal 5PGPR + compost tea.6-Biosoal + compost tea.

7- PGPR + Biosoal + compost tea.

C-Control (without inoculation are foliar spray).

Different soil addition and foliar spray added in the recommended rates.

PGPR inoculant (soil addition) :Mixed cultures of pink pigment facultative methyl trophic bacteria mainly, It was applied as foliar application at rat of $5 \mathrm{~L}$ fed -1 after 5 week from sowing. PPFM .F (Bacteria were kindly provide from Methylobacterium mesophilicum).and PPFM.C.

Preparation of PGPR (foliar spray): Plant Growth Promoting Rhizobacteria Pseudomonas sp. PGPR used in the present study is a commercial multi strains of Pseudomonas putida, Bacillus megatherium, Azospirillum brasilense produced by culture collection of Agric. Microbiology Dept. , ARC, Giza, Egypt. PGPR concentration was adjusted to $1 \times 10^{8}$ (cfu/gr) for all treatments and sprayed in the recommended times of cotton fertilization. 
Biosoal: was applied as a natural extract of multi Bacterial strain in two forms (soil adding and /or foliar spray)

Compost Tea: Compost tea is a liquid extract made by steeping compost in water using a variety of preparation methods (Ingham 2005)made brews when prepared by suspending a bag of compost in a container of water for up to 14 days to extract nutrients responsible to promotes integrity and vitality of treated plants. This type of brewing practice is called "passive" or Nonaerated Compost Tea and has been practiced for centuries. More recently, compost tea has been brewed in largescale mechanized systems for shorter periods of time and often supplemented with oxygen, nutrients, and microbial starter cultures to enhance the biological activity of the tea (Ingham, 2005, Naidu 2010)et al. This type of brewing technique is referred to as Aerated Compost Tea (ACT).ACT, has become more popular than nonaerated Compost tea, as an alternative to chemical fertilizers, pesticides and fungicides. It is used by organic farming communities, golf course managers,municipalities, and park and recreation facilities as part of an integrated pest management (IPM)practice. Benefits of ACT such as arising soil fertility, maximizing plant integrity and diseases suppression are reported by some users and advertised by the manufacturers of compost tea Al-Kahalet al., (2009).

\section{Management through plant growth:}

During the timed of the experiments different biofertilizer treatments were add as soil addition at seed sowing in $1^{\text {st }}$ of May during both seasons 45,65, 85 and 105 (soil addition and/ or foliar spray) days after sowing during two seasons. In addition, different agriculture managements (fertilizers, irrigation, pests control) were done according the recommended during 2013 and 2014 seasons.

Table 1. Physical and chemical properties of the experimental soil Agric. farm, Faculty of Agriculture, Moshtohor during 2013 and 2014 seasons.

\begin{tabular}{|c|c|c|}
\hline \multirow[t]{3}{*}{ properties } & \multicolumn{2}{|c|}{ Seasons } \\
\hline & 2013 & 2014 \\
\hline & \multicolumn{2}{|c|}{ Particle size distribution ( mechanical analysis ) } \\
\hline Course sand \% & 7.21 & 6.54 \\
\hline Find sand \% & 25.92 & 26.62 \\
\hline Silt \% & 12.86 & 13.62 \\
\hline Clay \% & 51.98 & 53.22 \\
\hline Texture grade & Clay & Clay \\
\hline \multicolumn{3}{|c|}{ Chemical analysis } \\
\hline E.C. & 2.15 & 2.18 \\
\hline pH (1:2.5) & 8.10 & 8.08 \\
\hline $\mathrm{CaCo}_{3} \%$ & 3.45 & 3.02 \\
\hline O.M \% & 2.13 & 2.20 \\
\hline N \% ( total) & 0.165 & 0.165 \\
\hline N(ppm) (available) & 51.05 & 52.63 \\
\hline$P \%($ total $)$ & 0.116 & 0.118 \\
\hline $\mathbf{P}(\mathbf{p p m})$ (available) & 19.4 & 20.81 \\
\hline K \% ( total) & 0.65 & 0.63 \\
\hline K(ppm) (available) & 937.75 & 996.35 \\
\hline \multicolumn{3}{|c|}{ Soluble captions and anions ( ppm ) } \\
\hline $\mathrm{Ca}^{++}$ & 185.6 & 192.6 \\
\hline $\mathrm{Mg}^{++}$ & 40.06 & 41.83 \\
\hline $\mathbf{K}^{+}$ & 42.64 & 41.81 \\
\hline $\mathrm{Na}^{+}$ & 191.42 & 191.25 \\
\hline $\mathrm{Cl}^{-}$ & 222.83 & 252.26 \\
\hline $\mathrm{Co}_{3}{ }^{--}$ & 0.00 & 0.00 \\
\hline $\mathrm{H} \mathrm{Co}_{3}^{-}$ & 344.28 & 365.37 \\
\hline $\mathrm{So}_{4}{ }^{--}$ & 491.96 & 461.12 \\
\hline
\end{tabular}

\section{Sampling and collecting data:-}

1-Growth characteristics: at 125 days of plant age i.e., 20 days after the last soil addition as well as the last foliar spray; ten plants randomly were taken from different treatments to count or measure each of Plant height $\mathrm{cm}$, number of vegetative branches, total leaf area $\mathrm{cm}^{2} /$ plant and number of fruiting.
2-Yield and yield componentsAll Institute, At harvest (i.e., 180 days after sowing ) samples of ten plants from the inner ridges of each subplot were randomly taken to determine the following yield attributes:Boll weight $(\mathrm{g})$, lint percentage, seed index (100 seeds weight $(\mathrm{g})$ ) and seed cotton yield g/plant and $\operatorname{Kentar}(157.5 \mathrm{~kg}) / \mathrm{fed}$.). 
*Fiber properties: Micronaire value, fiber maturity ratio (MR), upper half mean (UHM)mm, fiber uniformity index (UI), fiber reflected percent or brightness $(\mathrm{Rd}) \%$, yellowness degree $(+\mathrm{b})$, fiber strength $(\mathrm{g} /$ tex $)$ and fiber elongation percentage were determined using HVI instrument system according to (ASTM:D4605 1986).All properties were measured under standard conditions of $(65 \pm 5 \%)$ relative humidity and $\left(20 \pm 2 \mathrm{c}^{\circ}\right)$ room temp. The following fiber properties were measured using high volume Instrument (HVI). Fiber length parameters:Fiber length at upper half means (U.H.M) mm. - uniformity index (U.I)., Fiber bundle tensile: Fiber strength in gram / tex. - Fiber elongation \%: the percentage of elongation, which occurs before a fiber bundle breaks., Fineness characters: Fiber fineness (Micronaire reading). Fiber fineness was expressed as micronaire instrument reading, measured by (HVI), Color attributes values: Reflectance ( $\mathrm{Rd} \%)$ and Yellowness (+b), KEISOKKI kcf-v/ls version 1.29.3. The following fiber properties were measured using Keisokki (2013) kcf-v/ls version 1.29.3.Instrument High volume fiber Length test system and Fiber length parameters: Coefficient of variation length c.v \% - Spain length at $66.7 \%$ Spain length at 50 SL \% - Uniformity Ratio UR \%Short Fiber content (S.F.C. \%).

3-Yarn properties:

The R.S.S second part was spun fiber into (R.S.S) Ring spinning system $60^{\mathrm{s}}$ carded count yarns at 3.6 (T.M.) for tests of yarn properties. Skein strength was measured according to ASTM: D-156778, (1998). Neps, thick places, thin places per/100 meter and yarn evenness (C.V \%) was measured by Uster tester 3according to ASTM: D-1425-60, (1998). yet; fiber tests were conducted at a relative humidity of $65 \pm 2 \%$ and a temperature of $21 \pm 2{ }^{\circ} \mathrm{C}$.

4- Chemical analysis:

Samples of cotton leaves at 125 days after sowing were taken to determine, total nitrogen as described by Horneck and Miller (1998), phosphorus by Sandell (1950), potassium by Horneck and Hanson (1998). $\mathrm{Fe}, \mathrm{Zn}$ and $\mathrm{Cu}$ described by A.O.A.C. (1990). Total carbohydrates, were determined according to Dubois et al., (1956)and total chlorophyll were measured by using chlorophyll mater.(SPAD)

\section{5- Statistical analysis}

All data were statistically analyzed and the means were compared using the least significant difference Test (L.S.D.) at 5\% level according to Snedecor and Cochran (1998).

\section{Results and discussions}

\section{Growth characteristics:-}

Data in Table (2) indicate that different applied treatments i.e., Plant Growth Promoting
Rizobactria(PGPR) and Biosoal soil addition and foliar spray of PGPR, Biosoal, Compost Tea, PGPR. +Biosoal, PGPR+ Compost Tea, and PGPR+ biosoal + Compost Tea significantly increased plant height, number of vegetative branches, total leaf area/ plant, number of fruiting branches and total chlorophyll at 125 days after sowing during 2013 and 2014 seasons. The maximum of these traits was existed with foliar spray of combination of PGPR+ Biosoal+ Compost tea in two assigned seasons.

In this respect the maximum increase existed with the most of the applied treatments in growth aspects could be mainly attributed to the biofertilizers in which they could not only to (increase the availability of nutrients to cotton plant), but also they, function as phytostimulators thereby, stimulate and improve plant growth through creation of phytohormones known for a long time. In this respect, it was reported and established that $80 \%$ of microorganisms isolated from the rhizosphere of various crops possess the ability to synthesize and release auxins as secondary metabolites (patten and Glick, 1996, spaepen and vanderleyden of en., 2011 and Glick, 2012). Application of compost tea and biosoal to the root zone can increase plant yield and root growth significantly using extraction ratios. The compost tea effect on plant growth was found to be closely related to nitrogen status of the plant to the integrity.Carotenoids content, of vegetables is being closely related to plant growth(Pant et al., 2009). Natural microorganisms that live in fertile soil can increase plant integrity and vitality by variety of mechanisms (Haas and Défago, 2005) such asdirect association with roots; breakdown and release of minerals from organic matter to increase nutrient uptake in plants; Compost is comprised of a large and diverse community of microbes, humic acids and other chemicalnutrients such as carbon \& nitrogen that support soil and enhance plant growth and improve nutrient uptake by the plant. Haas, . and D. Défago (2005) and Glick, (2012)). 
Table 2. Effect of biofertilizers applied to the soil and /or foliar sprayed on growth characteristics of Egyptian cotton promising hybrid $10229 *$ G86at 125 DAS during 2013 and 2014 seasons.

Characteristics

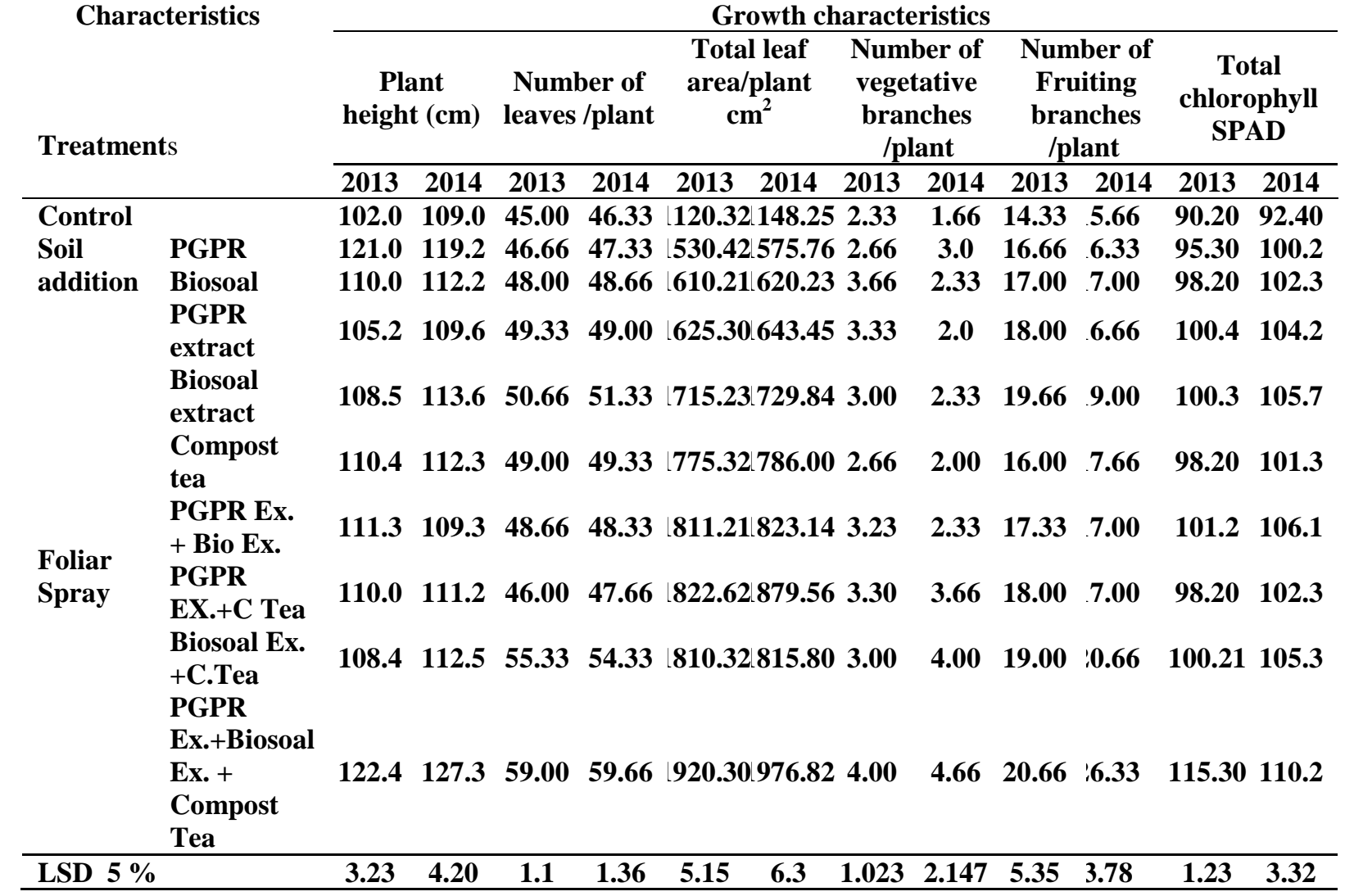

Yield and yield components:-

Data in Table (3) data show the effect of different applied treatments PGPR.and Biosoal as soil addition and foliar spray of PGPR, Biosoal, Compost tea, PGPR + Biosoal, PGPR + compost tea, Biosoal + Compost Tea and PGPR +Biosoal + compost tea on boll weight $(\mathrm{g})$, seed cotton yield $(\mathrm{g}) /$ plant, seed cotton yield (kantar) /feedan, lint $(\mathrm{g}) /$ plant, seed index $(\mathrm{g}) /$ plant and lint \% during 2013 and 2014 seasons. Different applied treatments significantly increased these traits during $1^{\text {st }}$ and $2^{\text {nd }}$ experimental seasons. The maximum increase obtained with using foliar spray of PGPR extract.+ Biosoal extract.+ compost tea during two experimental seasons. This increase by using PGPR+ Biosoal+ Compost tea could be attributed to those group of beneficial bacteria, as potentially useful for stimulating plant growth and increasing crop yields. That has been evolved over the past few years to where today researchers are being able to repeatedly use them successfully in field experiments. Increased growth and yields of clover Al-Kahal et al., (2009)., he reported. Commercial applications of PGPR are being tested and are frequently successful; however, a better understanding of the microbial interactions that result in plant growth will greatly increase or arisethe success rate of field applications (Burr et al., 1984). Also, in this respect PGPR, the rootcolonizing bacteria are known to influence plant growth by various direct or indirect mechanisms. Several chemical changes in soil are associated with PGPR. Plant growth-promoting bacteria (PGPB) are reported to influence the growth, yield, and nutrient uptake by an array of mechanisms. Some bacterial strains directly regulate plant physiology by mimicking synthesis of plant hormones, whereas others increase mineral and nitrogen availability in the soil as a way to augment portioning and translocation of different photosyntheates from source to sink thereby, increase plant yield and productivity. 
Table 3. Effect of biofertilizers applied to the soil and /or foliar sprayed on some yield and its components of Egyptian cotton promising hybrid $10229 *$ G86 at harvest time (i.e., 180 days after sowing) during 2013 and 2014 seasons.

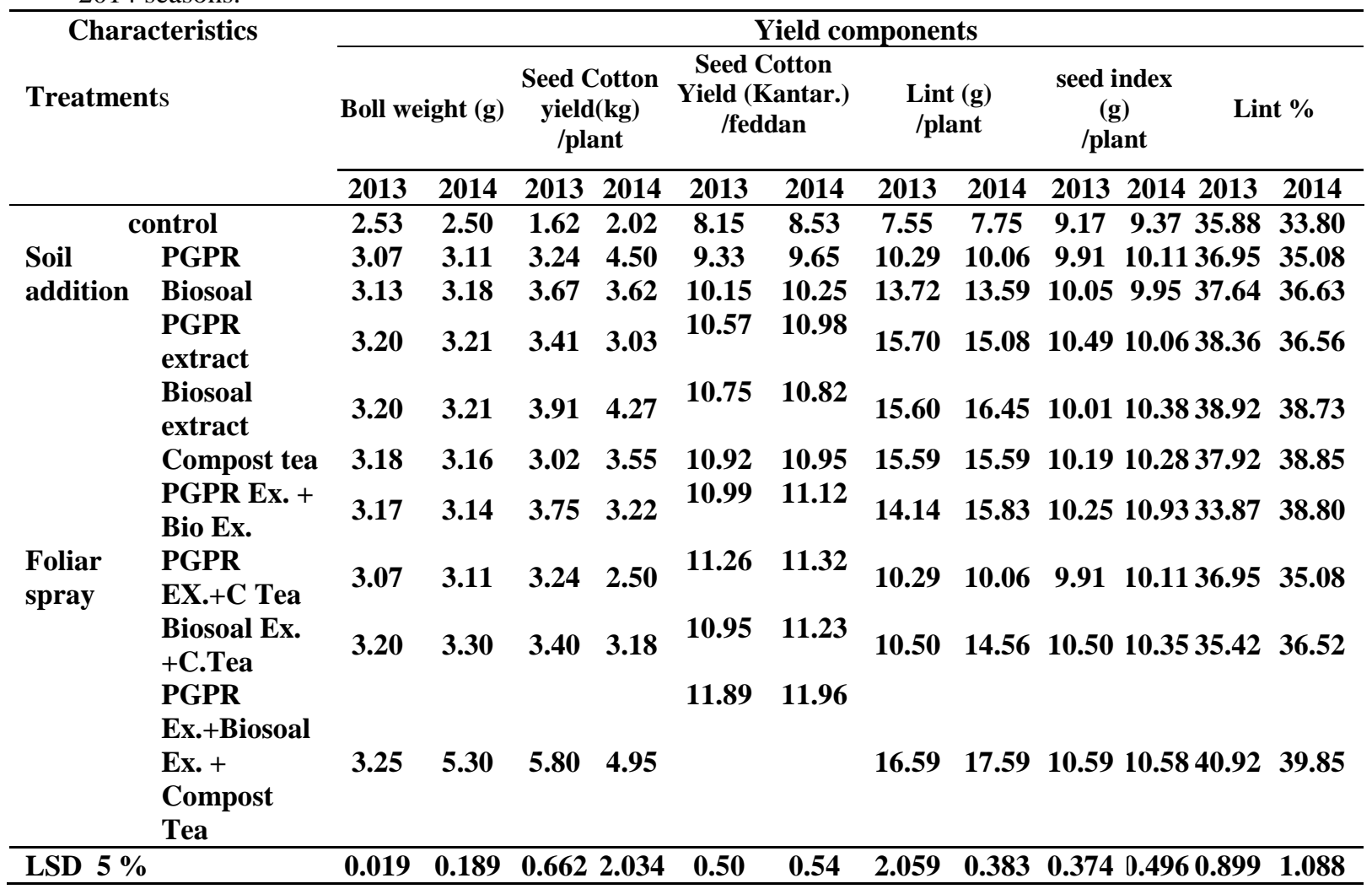

\section{Leaf Chemical composition:-}

Data presented in Table (4) indicate that control plants (without treatments) gave the lowest $\mathrm{N}, \mathrm{P}, \mathrm{K}, \mathrm{Fe}, \mathrm{Zn}$ and total carbohydrate in cotton leaves at 125 days after sowing during 2013 and 2014 seasons.Meanwhile, different applied treatments significantly increased thes eelements and carbohydrates to reach their maximumwith the applied combination of PGPR+Biosoal +Compost tea during $1^{\text {st }}$ and $2^{\text {nd }}$ experimental seasons. This increase in different elements and carbohydrates with using this combination of biofertilizers could be attributed to those attributed the beneficial effects of these treatments on minerals uptake and increase photosynthesis in cotton leaves the bacterial community in the rhizosphere develops depending on the nature and concentrations of organic constituents of exudates, and the corresponding ability of the bacteria to utilize these as sources of energy Phosphorus (P). Also, in this respect, Iron is the second important plant growth-limiting nutrient after nitrogen, is abundantly available in soils in both organic and inorganic forms Iron is a vital nutrient for almost all forms of life. All microorganisms known hitherto, with the exception of certain lactobacilli, essentially require iron (Neilands, 1995).In the aerobic environment, iron occurs principally as $\mathrm{Fe}^{+3}$ and is likely toform insoluble hydroxides and oxyhydroxides, thus making it generally inaccessible to both plants and microorganisms (Rajkumar et al., 2010). Commonly, bacteria acquire iron by the secretion of low-molecular mass iron chelators referred to as siderophores which have high association constants for complexing iron. Most of the siderophores are water-soluble and can be divided into extracellular siderophores and intracellular siderophore

Fiber properties:-

Data in Tables $(5,6 \& 7)$ indicated that different applied treatmentsi.e. PGPR and Biosoal addition in soiland foliar spray of PGPR;biosoal; compost Tea, PGPR +Biosoal; PGPR + Compost Tea;biosoal + Compost Tea and PGPR+biosoal + Compost tea significantly increasedSL2.5\%, SL 50\%, ML mm, UR\%,SFC\%, UHM m.m., UI\%, SL66.7\%, c.v\%, +b, $\mathrm{Rd} \%$, Elongation\%, Str. Gram/tex and Mic. for fiber properties during 2013 and 2014 seasons. The maximum increase also, was existed with using combination of foliar spray of PGPR +Biosoal+ compost tea during $1^{\text {st }}$ and $2^{\text {nd }}$ experimental seasons. In this respect, the obtained increase could be attributed to those beneficial effects of biostemulating microorganisms on growth and different physiological processes leading to increase photosyntheates formation by enhancing their translocation thereby; cause significantly increases in fiber properties. These bacteria, generally, improve the plant growth through direct effects on growth promoting, such as auxin and increasing the 
availability and uptake of soil nutrients. This prevent the damaging effects of the highly ions accumulation. The reduction in growth rate result which, reflected on the fiber quality as mentioned earlier. Thus its logic that the best interaction for all significant charactersAl-Kahal et al., (2009) and Glick, (2012).

Table 4. Effect of biofertilizers applied to the soil and /or foliar sprayed on chemical composition of leaves in Egyptian cotton promising hybrid $10229 *$ G86 at 125days after sowing during 2013 and 2014 seasons.

\begin{tabular}{|c|c|c|c|c|c|c|c|c|c|c|c|c|c|}
\hline \multicolumn{2}{|c|}{ Characteristics } & \multicolumn{12}{|c|}{ Chemical composition } \\
\hline & & \multicolumn{2}{|c|}{$\mathbf{N} \%$} & \multicolumn{2}{|c|}{$\mathbf{P} \%$} & \multicolumn{2}{|c|}{ K \% } & \multicolumn{2}{|c|}{ Fe mg/l } & \multicolumn{2}{|c|}{ Zn mg/l } & \multicolumn{2}{|c|}{$\begin{array}{c}\text { Total } \\
\text { carbohydrates } \\
\%\end{array}$} \\
\hline \multicolumn{2}{|c|}{ Treatments } & 2013 & 2014 & 2013 & 2014 & 2013 & 2014 & 2013 & 2014 & 2013 & 2014 & 2013 & 2014 \\
\hline \multirow{7}{*}{$\begin{array}{l}\text { Control } \\
\text { Soil } \\
\text { addition }\end{array}$} & & 2.03 & 2.15 & 0.52 & 0.58 & 1.56 & 1.62 & 220 & 225 & 124 & 134 & 15.30 & 16.45 \\
\hline & PGPR & 2.28 & 2.31 & 0.62 & 0.67 & 1.68 & 1.72 & 240 & 247 & 129 & 136 & 16.41 & 17.25 \\
\hline & Biosoal & 2.45 & 2.55 & 0.65 & 0.71 & 1.75 & 1.79 & 255 & 262 & 132 & 142 & 16.48 & 17.36 \\
\hline & $\begin{array}{l}\text { PGPR } \\
\text { extract }\end{array}$ & 2.35 & 2.42 & 0.71 & 0.74 & 1.83 & 1.86 & 266 & 273 & 145 & 152 & 16.52 & 17.69 \\
\hline & $\begin{array}{l}\text { Biosoal } \\
\text { extract }\end{array}$ & 2.53 & 2.60 & 0.78 & $\mathbf{0 . 8 3}$ & 1.91 & 1.95 & 275 & 279 & 155 & 161 & 16.82 & 17.95 \\
\hline & Compost tea & 2.75 & 2.80 & 0.81 & 0.86 & 1.95 & 1.98 & 278 & 287 & 160 & 169 & 16.90 & 17.99 \\
\hline & $\begin{array}{l}\text { PGPR Ex. + } \\
\text { Bio Ex. }\end{array}$ & 2.83 & 2.89 & 0.89 & 0.93 & 1.99 & 2.05 & 282 & 295 & 172 & 178 & 17.25 & 18.38 \\
\hline \multirow[t]{4}{*}{$\begin{array}{l}\text { Foliar } \\
\text { spray }\end{array}$} & $\begin{array}{l}\text { PGPR } \\
\text { EX.+C Tea }\end{array}$ & 2.91 & 2.94 & 0.92 & 0.98 & 2.00 & 2.09 & 289 & 312 & 179 & 186 & 17.89 & 18.47 \\
\hline & $\begin{array}{l}\text { Biosoal Ex. } \\
\text { +C.Tea }\end{array}$ & 2.80 & 2.84 & 0.93 & 0.99 & 2.10 & 2.15 & 293 & 316 & 187 & 192 & 17.90 & 18.35 \\
\hline & $\begin{array}{l}\text { PGPR } \\
\text { Ex.+Biosoal }\end{array}$ & & & & & & & & & & & & \\
\hline & $\begin{array}{l}\text { Ex. + } \\
\text { Compost } \\
\text { Tea }\end{array}$ & 3.01 & 3.03 & 1.01 & 1.05 & 2.66 & 2.73 & 310 & 323 & 196 & 202 & 18.23 & 19.89 \\
\hline \multicolumn{2}{|l|}{ LSD $5 \%$} & 0.20 & 0.22 & 0.12 & 0.18 & 0.15 & 0.22 & 0.11 & 0.13 & 0.10 & 0.11 & 0.15 & 0.20 \\
\hline
\end{tabular}

Table 5. Effect of biofertilizersapplied to the soil and /or foliar sprayed on fiber properties of Egyptian cotton promising hybrid 10229 X G86 during 2013 and 2014 seasons.

\begin{tabular}{|c|c|c|c|c|c|c|c|c|c|c|c|}
\hline \multirow{2}{*}{\multicolumn{2}{|c|}{ Characteristics }} & \multicolumn{10}{|c|}{ Fiber properties } \\
\hline & & \multicolumn{2}{|c|}{ SL2.5\% } & \multicolumn{2}{|c|}{ SL $50 \%$} & \multicolumn{2}{|c|}{ ML mm } & \multicolumn{2}{|c|}{ UR\% } & \multicolumn{2}{|c|}{ SFC\% } \\
\hline \multicolumn{2}{|c|}{ Treatments } & 2013 & 2014 & 2013 & 2014 & 2013 & 2014 & 2013 & 2014 & 2013 & 2014 \\
\hline \multirow{7}{*}{$\begin{array}{l}\text { Control } \\
\text { Soil } \\
\text { addition }\end{array}$} & & 34.67 & 35.37 & 16.60 & 16.80 & 30.03 & 29.03 & 47.87 & 45.90 & 4.97 & 3.40 \\
\hline & PGPR & 32.93 & 34.43 & 16.63 & 16.37 & 30.13 & 31.50 & 47.63 & 49.73 & 5.00 & 4.90 \\
\hline & Biosoal & 34.63 & 35.73 & 15.90 & 17.37 & 31.03 & 30.40 & 45.90 & 48.23 & 6.63 & 4.73 \\
\hline & PGPR extract & 34.93 & 34.63 & 16.37 & 15.90 & 30.90 & 30.13 & 47.30 & 49.07 & 4.73 & 5.00 \\
\hline & Biosoal extract & 34.33 & 34.12 & 17.37 & 16.60 & 31.50 & 29.90 & 49.73 & 48.23 & 3.40 & 4.00 \\
\hline & Compost tea & 34.83 & 32.93 & 16.80 & 16.63 & 30.40 & 30.23 & 48.23 & 47.30 & 4.90 & 4.97 \\
\hline & $\begin{array}{l}\text { PGPR Ex. + } \\
\text { Bio Ex. }\end{array}$ & 35.37 & 34.33 & 17.37 & 16.97 & 31.57 & 29.13 & 49.07 & 49.27 & 4.00 & 6.63 \\
\hline \multirow{3}{*}{$\begin{array}{l}\text { Foliar } \\
\text { spray }\end{array}$} & $\begin{array}{l}\text { PGPR EX.+C } \\
\text { Tea }\end{array}$ & 34.43 & 34.33 & 16.97 & 17.07 & 31.43 & 31.50 & 49.27 & 47.73 & 4.00 & 4.11 \\
\hline & $\begin{array}{l}\text { Biosoal Ex. } \\
+ \text { C.Tea }\end{array}$ & 34.50 & 34.55 & 17.20 & 17.4 & 31.40 & 31.6 & 49.50 & 47.60 & 5.30 & 4.25 \\
\hline & $\begin{array}{l}\text { PGPR } \\
\text { Ex.+Biosoal } \\
\text { Ex. + Compost } \\
\text { Tea }\end{array}$ & 35.73 & 34.83 & 17.47 & 17.97 & 32.80 & 31.52 & 49.73 & 49.87 & 6.47 & 6.36 \\
\hline \multicolumn{2}{|l|}{ LSD $5 \%$} & 0.705 & 0.88 & 1.122 & 1.23 & 1.799 & 1.89 & 2.822 & 2.87 & 2.378 & 2.47 \\
\hline
\end{tabular}


Table 6. Effect of biofertilizers applied to the soil and /or foliar sprayed on fiber properties of Egyptian cotton promising hybrid10229 X G86 during 2013 and 2014 seasons.

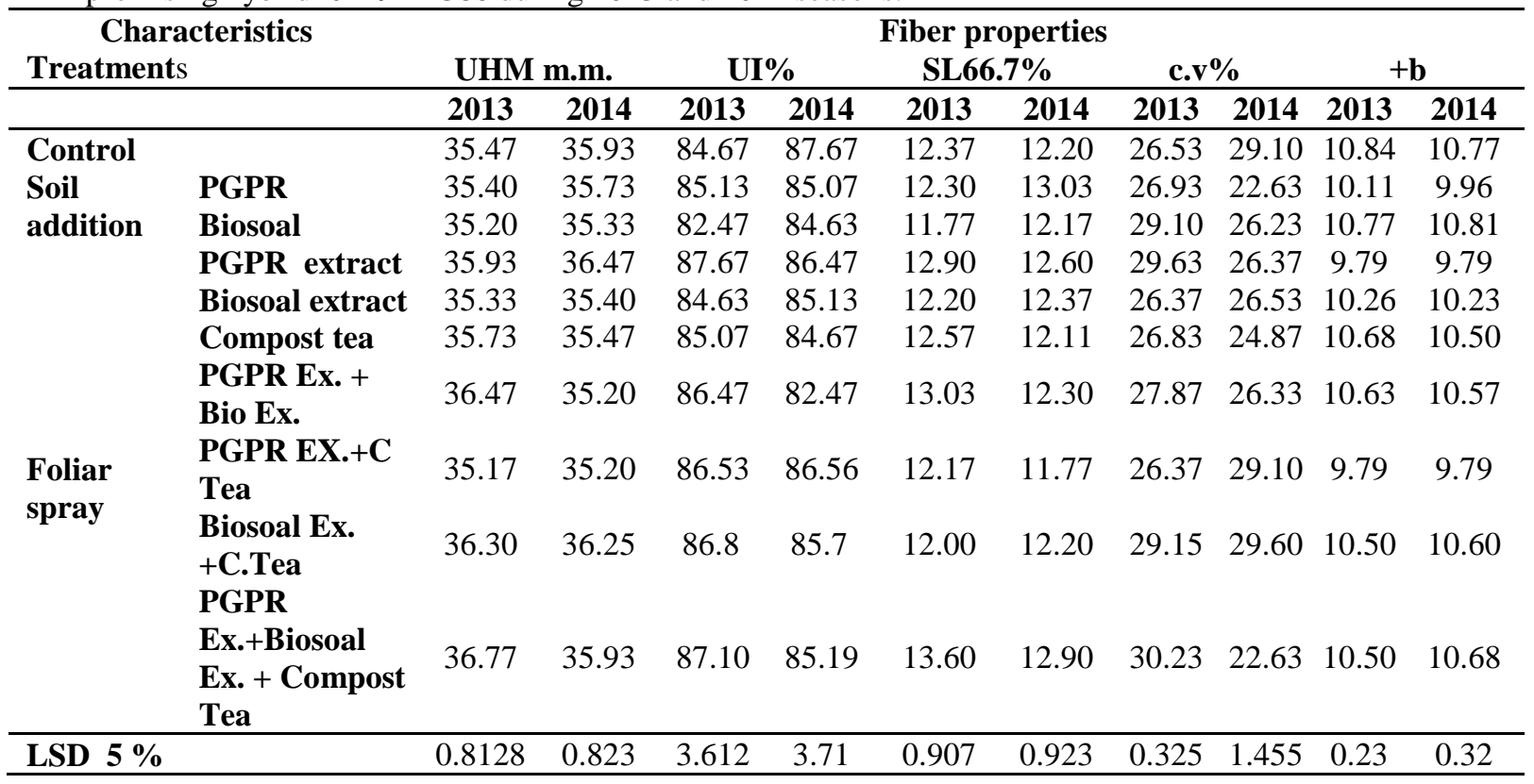

Table 7. Effect of biofertilizersapplied to the soil and /or foliar sprayed on fiber properties of Egyptian cotton promising hybrid 10229 x G86 during 2013 and 2014 seasons.

\begin{tabular}{|c|c|c|c|c|c|c|c|c|c|}
\hline \multicolumn{2}{|c|}{ Characteristics } & \multicolumn{8}{|c|}{ Fiber properties } \\
\hline & & \multicolumn{2}{|c|}{ Rd\% } & \multicolumn{2}{|c|}{ Elongation \% } & \multicolumn{2}{|c|}{ Str. Gram/tex } & \multicolumn{2}{|c|}{ Mic. } \\
\hline \multicolumn{2}{|c|}{ Treatments } & 2013 & 2014 & 2013 & 2014 & 2013 & 2014 & 2013 & 2014 \\
\hline \multirow{4}{*}{$\begin{array}{l}\text { Control } \\
\text { Soil } \\
\text { addition }\end{array}$} & & 55.85 & 56.18 & 8.65 & 7.99 & 28.6 & 29.42 & 4.4 & 4.3 \\
\hline & PGPR & 67.91 & 67.99 & 8.82 & 6.99 & 29.42 & 32.41 & 4.5 & 4.2 \\
\hline & Biosoal & 67.60 & 67.69 & 6.66 & 7.09 & 32.41 & 27.24 & 4.3 & 4.4 \\
\hline & PGPR extract & 67.90 & 67.97 & 7.65 & 7.65 & 27.24 & 32.6 & 4.2 & 4.4 \\
\hline \multirow{6}{*}{$\begin{array}{l}\text { Foliar } \\
\text { spray }\end{array}$} & Biosoal extract & 68.47 & 68.43 & 6.99 & 8.65 & 38.2 & 32.41 & 4.3 & 4.3 \\
\hline & Compost tea & 66.84 & 67.09 & 7.99 & 7.09 & 32.6 & 29.42 & 4.4 & 4.5 \\
\hline & $\begin{array}{l}\text { PGPR Ex. + Bio } \\
\text { Ex. }\end{array}$ & 65.80 & 55.26 & 7.09 & 8.82 & 35.22 & 35.22 & 4.5 & 4.3 \\
\hline & PGPR EX.+C Tea & 68.43 & 67.60 & 7.09 & 7.65 & 33.16 & 33.16 & 4.4 & 4.7 \\
\hline & Biosoal Ex. +C.Tea & 69.40 & 69.50 & 8.87 & 8.00 & 35.90 & 35.60 & 4.5 & 4.5 \\
\hline & $\begin{array}{l}\text { PGPR Ex.+Biosoal } \\
\text { Ex. + Compost Tea }\end{array}$ & 70.26 & 70.90 & 8.93 & 8.09 & 36.82 & 36.89 & 4.6 & 4.9 \\
\hline \multicolumn{2}{|l|}{ LSD $5 \%$} & 11.95 & 10.52 & 2.27 & 2.33 & 8.96 & 9.11 & 0.103 & 0.092 \\
\hline
\end{tabular}

Yarn properties:-

Data in Table (8) show the effect of different growth stimulating microorganisms PGPR and Biosoal as soil addition and foliar spray of PGPR ; biosoal ; compost tea; PGPR + biosoal ; PGPR + compost tea; biosoal+ compost tea; PGPR + biosoal + compost tea on yarn properties i.e.,(Skein strength, C.V.\%, Thin Places, Thick Places and Neps) during 2013 and 2014 seasons. In this context different applied treatments significantly increased skein strength during the two seasons. Meanwhile, C.V.\%, Thin Places, Thick Places and Neps decrease with different applied treatments during $1^{\text {st }}$ and $2^{\text {nd }}$ experimental seasons. Generally, the foliar spray with PGPR + biosoal + tea compost combination or separately increased fiber and yarn properties during $1^{\text {st }}$ and $2^{\text {nd }}$ seasons.

In this respect, this increase could be ascribed to the increase in fiber maturity as a result of good accumulation of carbohydrates which increase the cellulosic materials (non, colored materials) and decrease the non, cellulosic materials (colored materials) as found in plants grown under deficient of growth elements i.e., control (Pant et al., 2009) and Ahemad and Malik (2011). 
Table 8. Effect of biofertilizers applied to the soil and /or foliar sprayed on fiber properties of Egyptian cotton promising $10229 *$ during 2013 and 2014 seasons

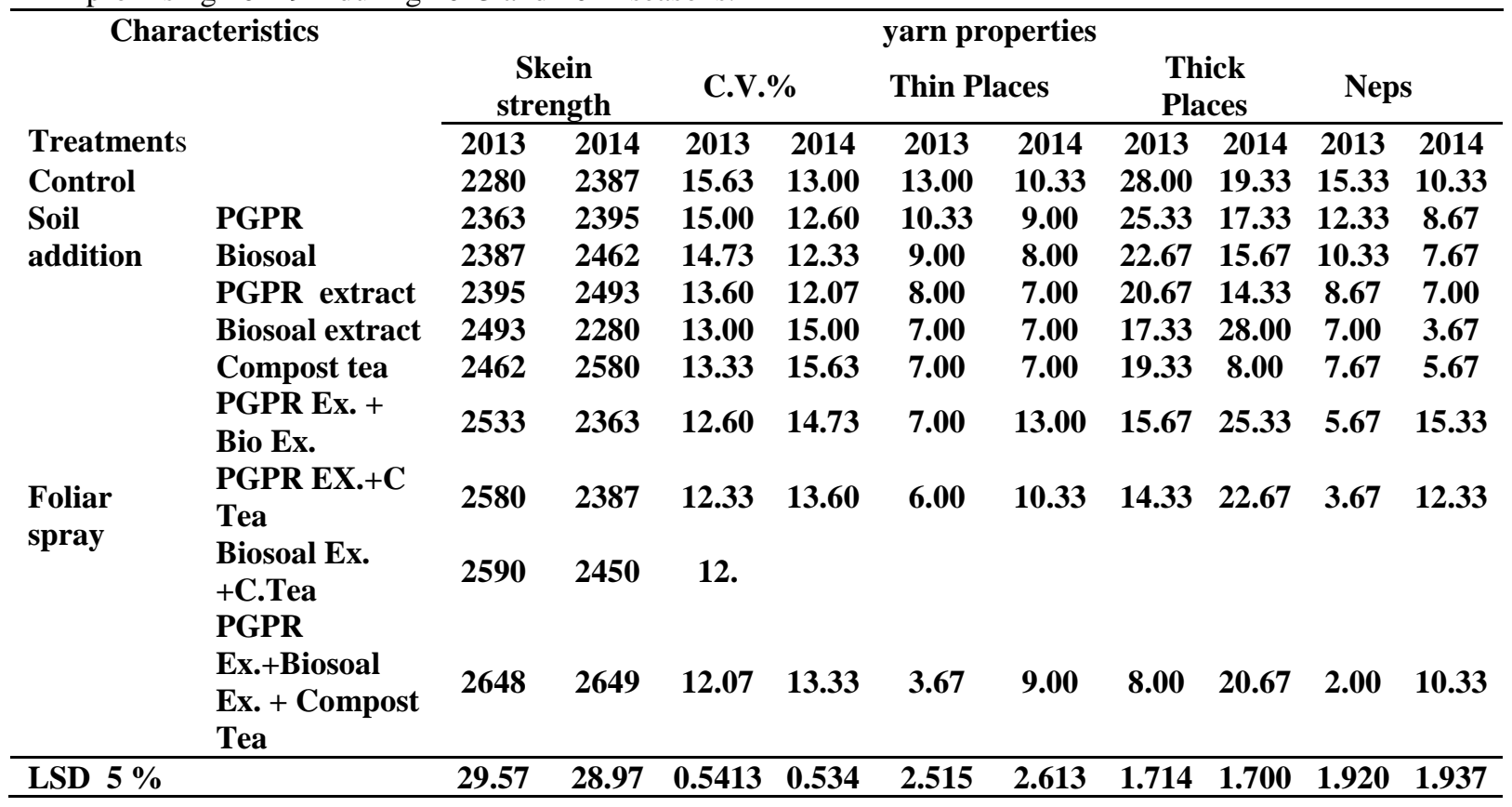

\section{References}

A.O. A. C. (1990).Official Method of Analysis, $15^{\text {th }}$ Ed., Association of Official Analytical Chemists, Inc., USA.

A.S.T.M. American Standard Testing and Materials (1998). On materials.D:1578-67:D:142560,D:1440-65,D1445-67,D:1448-68,D:2812-

95.Annu. Book of ASTM Standard.ASTM. Philadelphia, PA.

Ahmed, H.S.A. (2010). Effect of some treatments on growth and productivity in Egyptian cotton.Phd. Dept. of Agric Botany. Fac. of Agric. Moshtohor, Benha Univ.

Ahemad, M., and Maik.K.h.( 2009). Toxicity assessment of herbicides quizalafop-p-ethyl and clodinafop towards Rhizobium pea symbiosis.Bull. Environ. Contam.Toxicol. 82, 761-766.

Ahemad, M., 2010.Plant growth promoting activities of phosphate-solubilizing Enterobacterasburiae as influenced by fungicides.Eurasia. J. Biosci. 4, 88-95.

Ahemad, M. and Khan, M.S., (2011).Assessment of plant growthpromoting activities of rhizobacterium Pseudomonas putida underinsecticide-stress.Microbiol. J. 1, 54-64.

Ahemad, M. and Khan, M.S., (2012.Evaluation of plant growth promoting activities of rhizobacterium Pseudomonas putida under herbicide-stress. Ann. Microbiol. 62, 15311540.

Ahmed, H.S.A. (2002). Botanical studies on growth and flower abortion in cotton (Gossypium barbadense c.v) Plants. Msc. Dept. of Agric
Botany. Fac. of Agric. Moshtohor, Zagazig Univ. Benha branch.

Al-Kahal, A.A.;S.M. Ahmed ; W.D. Saleh and G.A.M. El-Sayed (2009). Productivity of clover as affected by application of compost tea, Egypt.J. of applied Sci., 24 (3B) 807-817.

Ambergerig, A. (1993). Dynamics of nutrients and reaction of fertilizers appelled on the environment.Proc. of German/ Egyptian/ Arab Workshop in Cairo and Ismailia, Egypt.6-17 June PP.41-60.

Armon, D.I. (1949). Copper enzymes in isolated chloroplast. Plant physiol., 24:1-15.

Arancon NQ, Edwards CA, Dick R and Dick L (2007) Vermicompost tea production and plant growth impacts.BioCycle 48 (11):51-52

ASTM.( 1986). American society for testing materials, D-4605. U.S.A.

Attia A.N., M.S. Sultan,E.M. Said, A.M. Zina and A.E. Khalifa (2008)Effect of the first irrigation time and fertilization treatments on the growth, yield, yield component in cotton

Braud, A., Je'ze'quel, K., Bazot, S. andLebeau, T., (2009). Enhanced phytoextraction of an agricultural $\mathrm{Cr}-, \mathrm{Hg}$ - and $\mathrm{Pb}$-contaminated soil by bioaugmentation with siderophoreproducing bacteria Chemosphere 74, 280-286.

Burr TJ, Caesar AM andSchrolh N, (1984). Beneficial plant bacteria. Critical Reviews in Plant Sciences, 2 (Suppl 1): 1-20.

Chandler, D., Davidson, G., Grant, W.P., Greaves, J. andTatchell, G.M., (2008). Microbial biopesticides for integrated crop management:an assessment of environmental 
and regulatory sustainability.Trends Food Sci. Tech. 19, 275-283.

Dhale D. A., S. N. Chatte and V. T. Jadhav(2011 )Response of bioinoculents on growth, yield and fiber quality of cotton under irrigation . Agricultural and biology journal of north America. Science $\mathrm{Huß,}$ http://www.scihub.org/ABJNA.

Dubios, M., K.A. Gilles, J.K. Hamilton, P.A. Rebe ns and F. Smith, (1956).“Colorimetric method for determination sugars and related substances",Anal. Chem. Soc., 46: 1662-1669.

Etesami H., H. A. Alikhani, M. Jadidi and A. Aliakbar (2009) Effect of Superior IAA Producing Rhizobia on N, P, K Uptake by Wheat Grown under Greenhouse Condition World Applied Sciences Journal 6 (12): 16291633.

Glick, B.R., (2012). Plant Growth-Promoting Bacteria: Mechanisms and Applications. Hindawi Publishing Corporation, Scientifica.Glick.

Hargreaves J, Adl MS, Warman PR andRupasinghe HPV (2008).The effects of organic amendments on mineral element uptake and fruit quality of raspberries. Plant Soil 308:213-226.

Haas, D. and G. Défago (2005); Biological Control of Soil-Borne Pathogens by Fluorescent Pseudomonads-Nature Review Microbiology.

Hayat, R., Ali, S., Amara, U., Khalid, R. and Ahmed, I., (2010). Soil beneficial bacteria and their role in plant growth promotion: a review. Ann Microbiol. 60, 579-598.

Horneck, D.A. and D. Hanson, 1998. "Determination of potassium and sodium by Flame Emission Spectrophotometry", In Handbook of Reference Methods for Plant Analysis, pp: 153-155

Horneck, D.A. and R.O. Miller, (1998). "Determination of total nitrogen in plant tissue",In Handbook of Reference Methods for Plant Analysis,pp:75-83..

Ingham ER (2005) The Compost Tea Brewing Manual; Latest Methods and Research.5th edn. Soil Food Web Inc., Corvallis, OR.

International Conference on Organic Farming (ICOF) (2010) Friendship Hall, Khartoum, Sudan 6 - 7 April 2010.

Jackson, M.L. (1976). Soil chemical analysis.Prentice- Hall, Inc. Engle Wood Cliffs, N.J., 498 PP.

KEISOKKI (2013) The following fiber properties were measured using Keisokkikcf-v/ls version 1.29.3.Instrument High volume fiber Length test system.kcf-v/ls version 1.29.3.
Li F.S., Xu Y.Z. and Zhang C. (1999).Effects of nitrogen, Phosphorus and potassium on the development of cotton bolls in summer.ActaGossypiiSinica 11: 24-30.

Maheshwari DK, Dubey RC, Aeron A, Kumar B, Kumar S, Tewari S and Arora NK (2012). Integrated approach for disease management a(nd growth enhancement of Sesamumindicum L. utilizing Azotobacterchroococcum TRA2 and chemical fertilizer. World $\mathbf{J}$ MicrobiolBiotechnol 28 (10):3015-3024.

Mitkees, R.A.; Ajman , M. Sadek; A.M.K. Eissa and Mahmoud, S.k. (1996). Use of nitrogen biofertilizer requirements. Nile valley and Red sea Regional program, Eight, Ann. Coordination Meeting, Egypt, 15-19 Sep., 140146.

Muhammad I; Khezir H and Noor I (2007).Study of Pix regulator effect on physiological responses in cotton plant Asian Journal of Plant Science, 6 (1), 87-92.

Naidu, Y., S. Meon, J. Kadir and Y. Siddiqui, (2010): Microbial Starter for the Enhancement ofBiological Activity of compost tea. Int. J.Agric. Biol., 12: 51-56.

Neilands, J.B., 1995. Siderophores: structure and function of microbial iron transport compounds. J. Biol. Chem. 270, 26723-26726.

Pant A, Radovich TJK, Hue NV, Talcott ST, Krenek KA (2009) Vermicompost extracts influencegrowth, mineral nutrients, phytonutrients and antioxidant activity in Pak choi (Brassica rapacv.Bonsai, Chinensis group) grown under vermicompost and chemical fertilizer. J Sci Food Agric 89:2383-2392

Patten, C.L. and Glick, B.R., (1996). Bacterial biosynthesis of indole-3-acetic acid.Can. J. Microbiol. 42, 207-220.

Rajkumar, M., Ae, N., Prasad, M.N.V. andFreitas, H., (2010).Potential of siderophore-producing bacteria for improving heavy metal phytoextraction.Trends Biotechnol. 28, 142149.

Sandell, R., (1950). "Colorimetric determination of traces of metal", 2ndEd.Interscience pub., Inc. New York.

Spaepen, S. and Vanderleyden, J., (2011).Auxin and plant-microbe interactions.Cold Spring Harb.Perspect.Biol. http://dx.doi.org/10.1101/cshperspect.a001438

tobacco phytopathology. 61: 126-1265.

SnedecorG.W andCochranW.G.(1998). Statistical Methods. $8^{\text {th }}$ Edition, Iowa State Univ., Press, Ames, Iowa. USA. 
تأثثير التسميد الحيوى بالبكتريا المشجعه للنمو والبيوسول والكمبوست السائل على النمو،المحصول ومكوناته وصفات جودة التيله والغزل فى الهجين المبشر 10229 *جيزة86 من القطن المصرى.

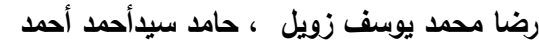 \\ قسم النبات الزراعى -كلية الزراعه - جامعة بنها "- معهد بحوث القطن مركز البحوث الزراعيه -الجيزة مصر . \\ الملخص العربى
}

أجريت تجرتان حقليتان بمحطة البحوث والتجارب بكلية الزراعه بمشتهر - جامعه بنها, وقياسات خصائص التيله بمعهد بحوث القطن مركز

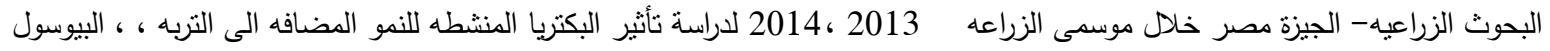

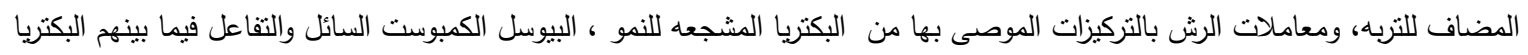

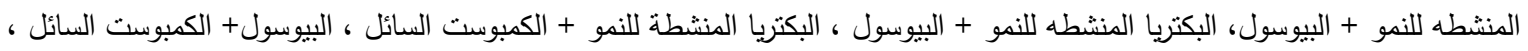

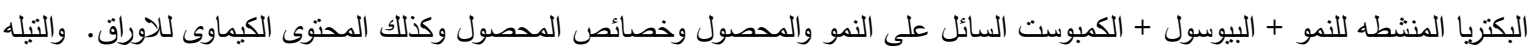

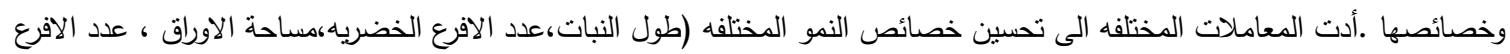

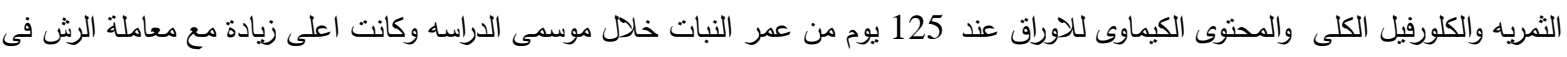

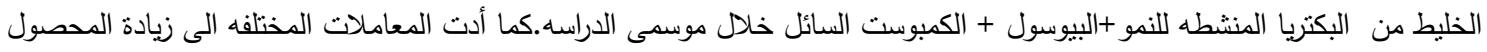

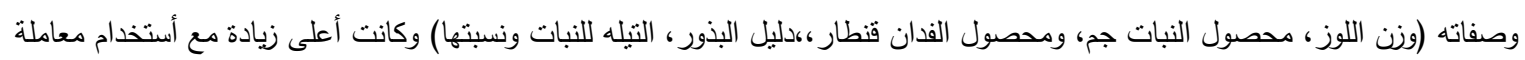

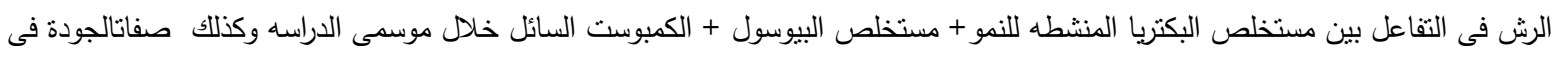

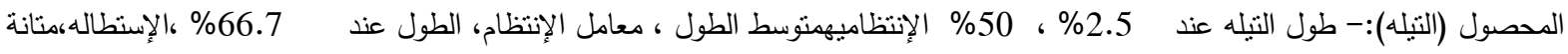
التيله،، إنخاض محتوى الثعبرات القصيرهمعامل الإختاف بالميكرونير ،الأماكن السميكه والرفيعه، والعقد - للخيط المغزول خلال موسمى الدراسه.

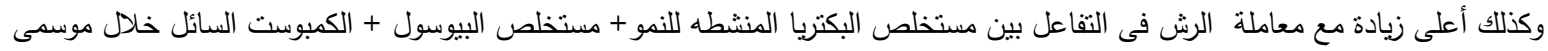
الدراسه. 